\title{
Technical efficiency and productivity of farms: a periurban case study analysis
}

\author{
Anna Gaviglio ${ }^{1}$, Rosalia Filippini ${ }^{1 *}$ (D, Fabio Albino Madau ${ }^{2}$, Maria Elena Marescotti ${ }^{1}$ and Eugenio Demartini ${ }^{1}$
}

\author{
* Correspondence: rosalia.filippini@ \\ unimi.it \\ ${ }^{1}$ Department of Health, Animal \\ Science and Food Safety, University \\ of Milan, Via Celoria, 2, 20133 \\ Milano, Italy \\ Full list of author information is \\ available at the end of the article
}

\begin{abstract}
Periurban farming systems are characterized by the need to adapt the farming practices coping with a modified natural and social environment. Questions are thus posed on the efficient use of the inputs. The purpose of this study is to estimate the technical efficiency and the productivity of periurban farms. To do so, the study employs a data envelopment analysis that properly captures the heterogeneity of the periurban farming system. The sample considered livestock and crop farms, located in the South Milan Agricultural Park, where 50 farms were selected and interviewed. Results show that crop farms are more efficient than livestock farms, but they have a less productive technology. The participation in short food supply chains and the multifunctional agriculture does not affect the levels of technical efficiency of the farms. Policies are thus needed to improve the education level of farmers and to sustain the efficiency of farms that diversify the farm's economy.
\end{abstract}

Keywords: Data envelopment analysis, Periurban farming system, Italy

\section{Introduction}

The periurban farming system (PFS) is defined as the farming system which is performed close to the urban area (FAO, 2010). The periurbanization is a process for which the rural area mixes with the urban area with consequences at territorial level (EEA, 2006). In Italy, this phenomenon is very relevant. Italy has a percentage of artificial surface higher than the community's average $7.8 \%$ versus $4.6 \%$, and almost all the national territory is characterized by a diffuse urbanization (ISPRA, 2015). Moreover, according to ISPRA (2015), almost $60 \%$ of the Italian urbanization process between 2008 and 2013 has taken place in agricultural areas, especially on arable land (48\%). The impact on the sustainability of the agricultural activity is thus relevant, especially because of the competition for the use of natural resources, such as land and water, which are critical inputs in the agriculture's production process. Considering the land for example, the urban pressure may lead to increase the land's prices both to buy and to rent, sometimes at the limit of land speculation (Quon, 1999). According to authors, in metropolitan areas, the constant loss of value of the agricultural land assets compared to the urban ones describes the most powerful push toward urbanization (Livanis et al., 2006; Sali et al., 2009; Pirani et al., 2016). As a reaction, farms in metropolitan areas may be pressured by high rents to adapt their farming practices. In this situation, farms have multiple options: they can improve their

(c) The Author(s). 2021 Open Access This article is licensed under a Creative Commons Attribution 4.0 International License, which permits use, sharing, adaptation, distribution and reproduction in any medium or format, as long as you give appropriate credit to the original author(s) and the source, provide a link to the Creative Commons licence, and indicate if changes were made. The images or other third party material in this article are included in the article's Creative Commons licence, unless indicated otherwise in a credit line to the material. If material is not included in the article's Creative Commons licence and your intended use is not permitted by statutory regulation or exceeds the permitted use, you will need to obtain permission directly from the copyright holder. To view a copy of this licence, visit http://creativecommons.org/licenses/by/4.0/. 
technical efficiency or technology, they can move towards production of higher valueadded and higher yield commodities (Ženka et al., 2016; Sokolow, 2003), they can intensify or make extensive the cropping systems (Zasada, 2011; Filippini et al., 2016a). In all these cases, in PFS, the response of each farm may be different and unique because of the specific urban pressure that farms are facing (Soulard et al., 2017). Moreover, at the socioeconomic level, farms may experience competition in labor market, which is another farming critical input. This may depend on the fact that urban jobs pay more than agriculture activity, and this reinforces the lack of turnover in the agricultural sector (European Parliament, 2018). Thus, how periurban farms have access and efficiently use the inputs may be compromised in PFS, with repercussion on the economic sustainability.

In this framework, to properly protect the PFS land and the farming economy supporting its innovations, several policies and actions are carried out. The agri-urban projects are those initiatives led by urban and periurban actors which combine agriculture and the city (Marraccini et al., 2013). In metropolitan areas, the development of agricultural parks, or agri-parks, is particularly encouraged as a way to protect agricultural land and maintain the agriculture around the metropolis (Paül and Mackanzie et al., 2013; Perrin et al., 2018). The development of agri-park relies on the multifunctional character of the land use where recreational and other social functions are combined with the farming activity and economy, which is used as a cost-efficient way of protecting and maintaining open spaces in the urban fringe (Jarrige et al., 2013). All these actions have the objective to exploit the local agriculture by supporting the link between urban dwellers and proximal farmers. To foster the PFS economic sustainability, usually farmers are invited to diversify their economic activity, through the multifunctional agriculture (Zasada, 2011) and the short food supply chains (SFSC) (Filippini et al., 2016b). Recreational services, social farming, and agritourisms are the most common multifunctional agriculture activities in periurban areas (Zasada, 2011), while the participation in farmers' markets located in the proximal urban areas, in solidarity purchasing groups, or the online and on-farm direct sale is the most common SFSC. According to literature, these economic activities allow periurban farmers to gain more profit, to diversify the risk among different food chains-conventional and alternativeand different economic sectors such as the agro-food one, tourism, and social services. For this reason, they are considered as an index of the adaptation of periurban farmers to the new urban demands and pressure and thus a way to maintain an economic viable agriculture in the periurban fringe (Aubry and Kebir, 2013; Paül e McKenzie 2013; Mastronardi et al., 2019).

Nevertheless, the effective impact of all those experiences on the economic sustainability of PFS has been questioned (Demartini et al 2017; Venn 2006; Filippini et al., 2016b). SFSCs are not always driven by food producers, and their goals are not necessarily farmers' profit maximization (Venn, 2006). The profit is uncertain and unstable over the time (Filippini et al., 2016b), thus hampering the farming long-term sustainability. Farmers engaging in SFSC and multifunctional agriculture have not always the relevant expertise, with repercussions on the efficient management of the activity (Filippini et al., 2016b). In metropolitan areas, scholars have argued that agri-urban projects may create also constraints in the use of the inputs, since they increase labor time and the potential for burnout, while revenues do not always consistently increase (Jarosz, 2008). Finally, in Italy, analysis has found no link between the multifunctional agriculture and the economic 
sustainability of periurban farms (Gaviglio et al., 2017). Especially, in the case of multifunctionality, the efficient use of the inputs by farmers was questioned (Gaviglio et al., 2017).

The efficient use of inputs in PFS is thus an open question because periurban farmers need to adapt the use of their inputs, such as land, due to the urban pressure and due to the pressure to diversify their economy. Being the efficient use of inputs one of the conditions for economic sustainability (De Koeijer et al., 2002; Gonçalves et al., 2009), the overall purpose of this study is to analyze the technical efficiency of periurban farms. In particular, the paper aims first to detect the technical efficiency of the farms in PFS and then to verify if the participation in SFSC and in multifunctional agriculture may impact the level of technical efficiency. The farms are localized in Italy, in the South Milan Agricultural Park (PASM), which is the first European Agri-park and which has the specific scope to capitalize the rural-urban link with agri-urban projects. To properly take into account the territorial heterogeneity of the PFS, the study employs a data envelopment analysis (DEA) to compute the technical efficiency scores of farms.

The article is organized as follows: the analytical framework that links together the economic sustainability and the farms technical efficiency is introduced in the "Economic sustainability, technical efficiency, and productivity of farms" section; the empirical model for the estimation of technical efficiency and productivity is presented in "Material and methods" section, along with the case study and the dataset and the applied model; the empirical findings are presented and discussed in the "Results" section; and, finally, concluding remarks are summarized in the "Conclusion" section.

\section{Economic sustainability, technical efficiency, and productivity of farms}

The farm's economic sustainability is defined by the current capacity of the farm to exist in the long term (Gaviglio et al, 2014). In other words, the farm is managed in a way that ensures its long-term sustainability. At territorial level, if the farm stops its activity, the land may be sold to other farms or to actors belonging to other economic sectors. Thus, the farm can be replaced either by other farms, or by other economic activities. In the former case, at sectoral level, the maintenance of the agricultural economy is not threaten, since the agriculture continues and probably in a more efficient way. In the second case, the replacement of the farming sector by another one may affect the overall importance of the agriculture in the area and at sectoral level. In periurban areas, the probability of replacing the farming activity by another economic sector is higher than in other rural areas. Thus, the analysis of how single farms are managed is crucial in analyzing the potential economic sustainability of PFS at territorial level (Gaviglio et al., 2014). Only recently, studies emphasize the need to study new solutions for improving the input efficiency in constrained territories such as urban and periurban areas (Opitz et al., 2015). According to literature, the economic sustainability analysis is not sufficient per se to understand the specific farm management decision making which is at the base of the sustainability's choices of the farmer (De Koeijer et al., 2002). Scholars have proposed to use the technical efficiency methodologies to provide evidence on the management capacity of farms, and thus insights on the capacity of the farms to be economically sustainable (De Koeijer et al., 2002; Gonçalves et al., 2009). Technical efficiency (TE) 
refers to the ability of the farms to attain the highest level of output given a set of inputs. The estimation of the farms' TE allows understanding if the farmer's decision making allow him to "doing things right" (Maietta, 2007). In other words, TE estimates allow understanding if farms are properly using the inputs at disposition, as well as the possible income gains resulting for an improvement of the inputs' use. It thus provides a measure of how the decision making of the farms support its sustainability (De Koeijer et al., 2002; Gonçalves Gomes and Soares de Mello, 2009).

In the TE analysis, it is assumed that it is possible to define an optimal level of inputs' transformation, and the analysis computes the actual ability of the farmer to transform the resources into output by the farm. The distance between the optimal level of efficiency and the actual farm's TE measures the technical inefficiency, which is interpreted as the failure of farms in producing the maximum output that is possible considering the inputs provided. Thus, the technical efficiency $\left(\mathrm{TE}_{i}\right)$ is calculated based on the ratio between the output obtained by the farm $y_{i}$ and the optimal standard $y_{i}^{*}$.

In this perspective, the productivity is usually defined as the relationship between the quantity of the product obtained (output) and the volume of one or more factors (inputs) required for its production. Thus, the productivity is the measure of the capacity of the farm to convert the inputs into the final output given a certain level of knowledge and technology. While TE provides a measure of the capacity of transforming the inputs, by measuring the degree of adherence to the observed production process to a standard of optimality-the so-called "Efficient production frontier"-the productivity measures the technological ground through which such transformation is possible (Lansink et al., 2002; Arru et al., 2019). Lansink et al. (2002) theorized that when comparing two different farming systems, the difference between their TE scores could be related to the different technologies the two farming systems have. In their contribution, they compare not only different farming practices-organic and conventional farming systems-but also different productions-livestock and cropping systems. These results had important implications at political level to better advice farm decision making.

The proposal of Lansink et al. (2002) seems appropriate for studies that want to compare different farming systems located in the same area. Especially it is suitable in the case of PFS. PFS in fact are characterized by farms that differently respond to the urban pressure and demand both considering the cropping system and the farming practices and considering the economic diversification (Soulard et al., 2017; Zasada, 2011; Filippini et al., 2018). At the same time, the differentiation and comparison of different farming systems is important when farms are working under the same political umbrella, such as agri-parks, sharing the same territorial policies and pressures. In this context, according to literature, the policies and analysis should adopt a territorial approach, where the heterogeneity of the farming systems is taken into account (Torreggiani et al., 2012), as in the case of PFS.

TE models are widely used in farming system analysis to study the technical performances of farms (Roco et al., 2017; Theodoris et al., 2014). Usually, the models first determine the TE of farms and then the factors explaining such efficiency. The TE usually compares the level of gross output with the level of inputs, which in case of farms solely are the land, the labor, the different variable costs, and the capital. Usually, age and education are discussed as potential factors of efficiency (Karimov, 2014). Farmers that are more 
educated are considered more prone to be efficient farms (Latruffe et al., 2004; Theodoris et al., 2014). Younger farmers can be more prone to adopt input-saving innovative technologies, or on the contrary, older farmers are more efficient, since they can rely on a longer practical experience in addressing the efficiency stakes (Hadley, 2006). To our knowledge, few studies have been applied in periurban areas and are considering the PFS heterogeneity of the different farming systems operating. Most analysis are focused only on specific farming systems, such as livestock (Van Rensburg and Mulugeta, 2016; Theodoridis et al., 2014; Furesi et al., 2013; Madau et al., 2017), fruit (Madau et al., 2015), and cereals (Madau et al., 2007). On the contrary, few studies have compared different farming systems and their different market orientation between local and global food chains (Lohr, and Park, 2010). Especially, few of them have employed a productivity measure to discuss the farms' TE levels in terms of their technology (Lansink et al., 2002; Mayen et al., 2010). The inclusion of the technology ground of the farming systems in the analysis allow to verify if the differences in the farms' performances are due to a less productive technology, to a lower TE in production, or both. This aspect is important in addressing policies in specific areas.

Up to now, the literature on TE models applied in PFS is focused in developing countries (Binam et al., 2004; Asogwa et al., 2012). These studies are not comparable with European and Italian case studies. On the contrary, this study wants to provide insights on the TE and the productivity of farms located in a productive agricultural area, but under urban pressure and under the political umbrella of an agricultural park, which asks farms to follow rules in the production and economy's diversification (Perrin et al., 2018). In this sense, only recent studies have tested the impact of the economic diversification on the levels of TE (Lohr and Park; 2010; Bauman et al., 2019; Arru et al., 2019). The interest on the impact of economic diversification's activities on the level of $\mathrm{TE}$ is justified by the increasing interest that institutional bodies and scholars are assigning to such activities that are seen as drivers of economic sustainability for farmers, but no research on the TE of farms participating (Lohr and Park; 2010; Bauman et al., 2019).

\section{Materials and methods}

\section{Case study}

The case study is the area of the South Milan Agricultural Park (PASM) (Fig. 1). The PASM is a regional metropolitan agricultural park embracing the southern, eastern, and western areas of the city of Milan (northern Italy), one of the most highly productive agricultural regions in Europe. The park was created in 1990 to protect and sustain the natural ecosystems and to safeguard, qualify, and promote agricultural land and activities. It was conceived to provide green areas available to urban dwellers and to protect farmers' economy, avoiding the loss of agricultural land due to urban pressure. In fact, despite the highly productive agriculture, the proximity to the metropolis of Milan is a strong push to convert land from agriculture to urban purposes. The PASM includes 61 municipalities and covers an area of about 47,000 ha, of which approximately 37,000 ha of agricultural surface and 19,000 ha of urbanized territory. The park includes only plain area. The area involves approximately 576 farms, characterized by intensive farming practices. The main crops are maize, rice, permanent meadows, 


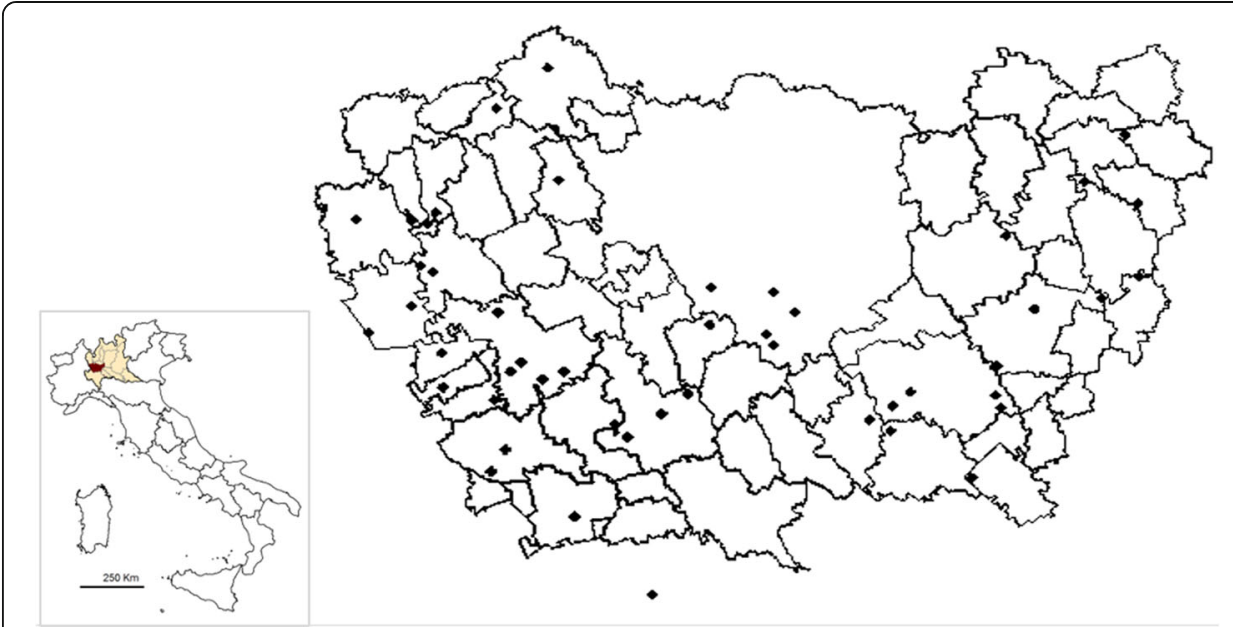

Fig. 1 Case study. The points identify the farms

soybean, winter barley, Italian ryegrass, and winter wheat. The main livestock are cattle, poultry, and pigs. In the area, farms can sell their products to big retailers, to big processors, or directly to consumers through SFSCs (Gaviglio et al., 2014). Since its establishment, the PASM actions over the agriculture performed in the area have been especially focused on valorizing the natural aspects of the area, as well as to valorize the activities performed by farmers that can strengthen the link with the closer Milan urban residents: SFSCs, the agritourisms, and recreational activities. Such activities are ruled by several documents: the Norme Tecniche di Attuazione (NTA, Technical Norms) and the Piano di Settore Agricolo (PSA, Agricultural Plan). They contain a large number of rules and regulations aimed to (i) protect the agricultural activities, (ii) promote new job opportunities in the agricultural sector, especially young people, (iii) introduce more sustainable farming practices and lower impact agronomic techniques such as organic farming, and (iv) enhance the landscape, the environment, the cultural and historical heritage, and protect the water resources ${ }^{1}$. A specific interest is in the creation of new job opportunities in the agricultural sector, especially young people, and in enhancing the landscape, the environment, and the cultural and historical heritage (Città Metropolitana di Milano, 2007).

In this area, the project "Osservatorio economico-ambientale per l'innovazione del Parco Agricolo Sud Milano" (Economic Observatory for Innovation of the South Milan Agricultural Park $)^{2}$ had the purpose to verify the economic, environmental, and social sustainability of the farms to develop a support, the 4Agro, for the Park management. Resulting from a stratification process (Gaviglio et al., 2014), 50 farms were sampled to represent the four areas' characteristic of the PASM. In 2015-2016 semi-structured interviews were conducted to the farms (Fig. 1). For a detailed description of the sample stratification process, please see Gaviglio et al., 2014.

For the purpose of this study, six farms were excluded from the analysis since their revenues were lower than 50,000 euro per year. In this way, it was possible to select

\footnotetext{
${ }^{1}$ Information on http://www.provincia.mi.it/parcosud/index.jsp

${ }^{2}$ For a detailed description of the project, please visit http://www.cittametropolitana.mi.it/parco_agricolo_ sud_milano/agricoltura/sitpas/sitpas_osservatorio.html
} 
professional farms and to homogenize the economic value of the sample. Table 1 summarizes the characteristics of the 44 farms where the DEA was finally applied. As it is possible to see, in the sample, most of the farms have multifunctional agriculture and participate in SFSC, making the case study relevant for the purpose of this study.

\section{Empirical model}

Technical efficiency (TE) can be estimated through parametric and not parametric methods. The stochastic frontier analysis is a parametric method, which assumes that the deviation from the efficient frontier depends on the farm's inefficiency, thus the farmer decision-making, and a stochastic parameter that is not controlled by farmers (Bauer, 1990). The problem with this method is that it assumes a parametric specification for the production technology, which in the end can affect the efficiency results (Lansink et al., 2002). The data envelopment analysis (DEA) is a non-parametric approach for estimating TE (TE) (Charnes et al. 1978). Solving a linear programming problem, DEA calculates the efficiency by comparing each production unit against all other units. Since it does not assume a productive technology, the method is suitable for samples for which the technological ground is not known, as well as for small sample size, because a frontier is built without considering the statistical variability of the observed data in determining the efficiency. The DEA estimates the TE of each productive decision-making units (DMUs) taking into account the resources used by the units and the results they obtain. DEA models optimize the efficiency index of each individual DMU in order to estimate an efficient piecewise linear frontier. The DMUs with higher TE scores become the benchmarks for the inefficient ones. The remaining DMUs will have an efficiency score between 0 and 1 inversely proportional to their distance from the frontier. In the study, we employed an output-oriented approach to calculate both constant return to scale $\left(\mathrm{TE}^{\mathrm{CRS}}\right)$ and variable return to scale $\left(\mathrm{TE}^{\mathrm{VRS}}\right)$ technical efficiency. The methodology follows several steps.

Table 1 Characteristics of the analyzed sample. Multifunctional agriculture and SFSC are explained in Table 2

\begin{tabular}{lll}
\hline Farms' characteristics & N. & $\%$ \\
\hline Farming System & 25 & $57 \%$ \\
Crops & 19 & $43 \%$ \\
Livestock & & \\
Usable agricultural area (UAA) & 18 & $41 \%$ \\
$<50$ ha & 17 & $39 \%$ \\
$50-100$ ha & 9 & $20 \%$ \\
$>100$ ha & & $89 \%$ \\
Multifunctional agriculture & 39 & $11 \%$ \\
Yes & 5 & $75 \%$ \\
No & & $95 \%$ \\
Food chain & 33 & \\
Farms in short food supply chains (SFSC) & 42 & \\
Farms in conventional food chains (CFC) & & \\
\hline
\end{tabular}


(i) Firstly, $\mathrm{TE}^{\mathrm{CRS}}$ and $\mathrm{TE}^{\mathrm{VRS}}$ scores were estimated using the software NLogit 5 (Greene, 2011) for each farm. The difference between the two TE measures is that $\mathrm{TE}^{\mathrm{VRS}}$ represents the TE without the scale efficiency effect, and thus, it measures the efficiencies as due to only managerial performance. For this reason, it is also called the pure TE.

The $\mathrm{TE}^{\mathrm{CRS}}$ for a single output is derived by solving the following linear programming model (1):

$$
\begin{aligned}
& \max _{\theta, \lambda} \theta_{i} \text { s.t. } \\
& \sum_{j=1}^{n} \lambda_{j} y_{j}-\theta_{i} y_{i}-s=0 \\
& \sum_{j=1}^{n} \lambda_{j} x_{k j}+e_{k}=x k_{i} \\
& \lambda_{j} \geq 0 ; s \geq 0 ; e_{k} \geq 0
\end{aligned}
$$

where $\theta_{i}$ is the proportional increase in output possible for the $\mathrm{i}$-th farm, $\lambda_{j}$ is an $\mathrm{N} \times 1$ vector of weights relative to the efficiency observation, $s$ is the output slack, and $e_{k}$ is the $\mathrm{k}$-th input slack. Banker et al. suggested that the TE ${ }^{\mathrm{CRS}}$ model should be adapted to account for a VRS situation. Thus, by adding the convexity constraint N1' $\lambda=1$, the model can be modified into the TE ${ }^{\mathrm{VRS}} \mathrm{DEA}$.

A farm has efficient results when the values of $\theta_{i}$ and $\lambda_{i}$ are equal to 1 and $\lambda_{j}=0$. In contrast, an observation is inefficient when $\theta_{i}>1, \lambda_{i}=0$, and $\lambda_{j} \neq 0$. Solving (1), it is possible to obtain a measure of TE that reflects the distance between the farm's observed and optimal output production for a certain input bundle:

$$
\mathrm{TE}_{i}=\frac{Y_{i}}{Y_{i}^{*}}=\frac{1}{\theta_{i}}=0 \leq \mathrm{TE} \leq 1
$$

where $Y_{i}$ is the maximum possible (optimal) output and $Y_{i}^{*}$ is the observed outputs.

Then, a measure of scale efficiency (SE) is obtained by comparing the $\mathrm{TE}^{\mathrm{CRS}}$ and $\mathrm{TE}^{\mathrm{VRS}}$ scores, applying (3)

$$
\mathrm{SE}=\frac{\mathrm{TE}}{\mathrm{TE}} \mathrm{ERS}^{\mathrm{VRS}}
$$

Any difference between the two TE scores indicates that there is scale inefficiency that limits the achievement of an optimal (constant) scale (CRS).

(ii) The sample was divided in two groups: livestock farms and crop farms. To verify whether these farms were in a separated frontier function, due to a difference in the technological ground, following Lansink et al. (2002), the TE was then separately estimated for the two sub-groups (livestock and crop farms). Two production frontiers were estimated, one for crop farms only and the other for livestock farms only. In this end, for each farming system, two TE resulted: an estimation of the TE of crop (and livestock) farms calculated considering the two groups as in one unique frontier, the overall group TE $\left(T E_{o}\right)$, and an estimation of the TE of crop (and livestock) farms calculated considering the two farming 
systems as belonging to two different frontiers $\left(\mathrm{TE}_{g}\right)$. According to Lansink et al. (2002), the $T E_{o}$ is related to the $T E_{g}$ by a productivity factor $\phi$ which indicates the difference between the two farming systems' frontiers.

$\mathrm{TE}_{o}=\phi * \mathrm{TE}_{\mathrm{g}}$

The productivity index for the two farming systems is thus calculated following (4).

$$
\phi=\frac{\mathrm{TE}_{\mathrm{o}}}{\mathrm{TE}_{\mathrm{g}}}
$$

where $\phi$ is the productivity factor, $\mathrm{TE}_{\mathrm{o}}$ represents the TE crop (or livestock) farms of the overall group, thus considering the two groups of farms as in one unique production frontier, $\mathrm{TE}_{\mathrm{g}}$ represents the $\mathrm{TE}$ of sub-groups, thus calculating separately the production frontiers for the two farming systems, in this study livestock and crops farms. The hypothesis to test is if the difference between the TE scores is due to inefficient use of the inputs or to a different technology used by the two groups of farms. A $t$-test statistic was then applied to verify if the TE scores of the two farming systems were significantly different. If a statistically significant difference was found, the two sub-groups belong to two different production frontiers. In other words, it would mean that the there is no technological homogeneity between the two farming systems (Arru et al., 2019; Lansink et al., 2002).

(iii) Following Lansink et al., (2002) a single-input TE was estimated to verify the role of single inputs in describing the frontier, using DEAP 2.1 created by Coelli (1996). With this measure, it was possible to estimate the TE related to each input and the specific margin saved by each input to achieve full efficiency, assuming the rest of the inputs and the final output do not change.

(iv) To determine whether a farm operates under increasing return to scale (IRS) or decreasing return to scale (DRS), a non-increasing return to scale ( $\mathrm{TE}^{\mathrm{NIRS}}$ ) condition on the DEA model is imposed (Coelli et al. 1998), so if $\mathrm{TE}^{\mathrm{CRS}}=\mathrm{TE}^{\mathrm{VRS}}$, the farm is operating under CRS; if $\mathrm{TE}^{\mathrm{NIRS}}=\mathrm{TE}^{\mathrm{VRS}}$, the farm is operating under DRS; if $\mathrm{TE}^{\mathrm{CRS}} \neq \mathrm{TE}^{\mathrm{VRS}}$, the farm is operating under IRS.

(v) Finally, as done in other scientific contributions (Latruffe et al., 2004; Bauman et al., 2019), a discriminatory analysis was then applied to test the impact of demographic and socio-economic factors on the levels of TE. Specifically, we tested whether the level of TE is statistically significant different among farmers using variables that refer to the demographic characteristics of farms and the economic diversification strategy.

\section{The data}

Data are based on semi-structured interviews performed in 2015-2016 to farmers. Table 2 describes the variables used for the DEA, as well as their main statistics, considering the sample and divided according the two farming systems, livestock and crops. The output variable is the total revenues of the farms from the sale of the product in both SFSC and CFC and including the CAP payments. The input variables are land in terms of hectares, variable costs, and the labor both familiar and not familiar. 
Table 2 Description of the data envelopment analysis' input variables and variables of the $t$-test; average values (av) and standard deviation (st.dev)

\begin{tabular}{|c|c|c|c|c|c|c|}
\hline Variables & Unit & Description & $\begin{array}{l}\text { Total } \\
\text { sample } \\
\text { av } \\
\text { (st.dev) }\end{array}$ & $\begin{array}{l}\text { Total } \\
\text { sample } \\
\text { max- } \\
\text { min }\end{array}$ & $\begin{array}{l}\text { Livestock } \\
\text { farms av } \\
\text { (st.dev) }\end{array}$ & $\begin{array}{l}\text { Crop } \\
\text { farms av } \\
\text { (st.dev) }\end{array}$ \\
\hline \multicolumn{7}{|l|}{ Output } \\
\hline Revenues & $€^{\prime} 000$ & $\begin{array}{l}\text { Total revenues of the farm, including } \\
\text { revenues from the sale of the product, the } \\
\text { revenues from multifunctional agriculture, } \\
\text { CAP payment. }\end{array}$ & $\begin{array}{l}519.33 \\
(603.33)\end{array}$ & $\begin{array}{l}2977.97- \\
77.00\end{array}$ & $\begin{array}{l}731.96 \\
(825.95)\end{array}$ & $\begin{array}{l}357.72 \\
(278.49)\end{array}$ \\
\hline \multicolumn{7}{|c|}{ Input } \\
\hline Land & ha & Usable agricultural area & $78(76)$ & $404-5$ & $90(91)$ & $70(62)$ \\
\hline EXPE & $€^{\prime} 000$ & $\begin{array}{l}\text { Variable costs of the farm: purchase of } \\
\text { seeds, seedlings, fertilizers, plant protection } \\
\text { products, veterinary expenses (materials + } \\
\text { work performance), fodder, feed, irrigating } \\
\text { water, electricity, fuels (methane, LPG, } \\
\text { other), insurances, accounting technical } \\
\text { consultancy, banking services, membership } \\
\text { fees for trade associations, rental of } \\
\text { machinery, means of transport and other } \\
\text { goods, agricultural work performed by } \\
\text { third parties, charges for the management } \\
\text { of the farm, fuels }\end{array}$ & $\begin{array}{l}187.76 \\
(356.39)\end{array}$ & $\begin{array}{l}2059.71- \\
13.07\end{array}$ & $\begin{array}{l}346.50 \\
(540.77)\end{array}$ & $\begin{array}{l}108.65 \\
(77.61)\end{array}$ \\
\hline Work & $€^{\prime} 000$ & $\begin{array}{l}\text { Cost for familiar and non-familiar } \\
\text { manpower }\end{array}$ & $\begin{array}{l}121.738 \\
(966.3)\end{array}$ & $\begin{array}{l}535.50- \\
28.80\end{array}$ & $\begin{array}{l}137.62 \\
(83.44)\end{array}$ & $\begin{array}{l}109.67 \\
(105.63)\end{array}$ \\
\hline \multicolumn{7}{|c|}{ Discriminatory analysis } \\
\hline VALT & $\%$ & $\begin{array}{l}\text { Percentage of total revenues from SFSCs: } \\
\text { direct on-farm sale, food processing and } \\
\text { sale, sale in farmers markets, groceries, } \\
\text { schools' canteens, solidarity purchasing } \\
\text { groups. }\end{array}$ & $\begin{array}{l}14.16 \\
(19.09)\end{array}$ & $\begin{array}{l}98.56- \\
0.00\end{array}$ & $\begin{array}{l}14.18 \\
(22.74)\end{array}$ & $\begin{array}{l}14.16 \\
(16.29)\end{array}$ \\
\hline VCONV & $\%$ & Percentage of total revenues from CFNs & $64.5(27.6)$ & $\begin{array}{l}94.77- \\
0.00\end{array}$ & $\begin{array}{l}72.12 \\
(22.30)\end{array}$ & $\begin{array}{l}58.14 \\
(25.21)\end{array}$ \\
\hline MULT & $\%$ & $\begin{array}{l}\text { Percentage of total revenues from } \\
\text { multifunctional agriculture: didactic farms, } \\
\text { agritourism, sub-contractor, on-farm } \\
\text { processing }\end{array}$ & $\begin{array}{l}29.50 \\
(32.94)\end{array}$ & $\begin{array}{l}98.56- \\
0.00\end{array}$ & $\begin{array}{l}8.58 \\
(22.10)\end{array}$ & $\begin{array}{l}20.47 \\
(28.23)\end{array}$ \\
\hline AGE & $\%$ & $\begin{array}{l}\text { Percentage of employers younger than } 40 \\
\text { years old }\end{array}$ & $\begin{array}{l}25.34 \\
(20.52)\end{array}$ & $\begin{array}{l}60.68- \\
0.00\end{array}$ & $\begin{array}{l}32.61 \\
(20.82)\end{array}$ & $\begin{array}{l}19.82 \\
(18.86)\end{array}$ \\
\hline EDUC & $\%$ & $\begin{array}{l}\text { Percentage of employers with high school } \\
\text { or university diploma }\end{array}$ & $\begin{array}{l}73.63 \\
(27.27)\end{array}$ & $\begin{array}{l}100.00- \\
0.00\end{array}$ & $\begin{array}{l}71.03 \\
(23.29)\end{array}$ & $\begin{array}{l}76.61 \\
(30.27)\end{array}$ \\
\hline
\end{tabular}

For the $t$-test, two categories of variables were considered: three economic variables and two demographic variables. The economic variables refer to the percentage of sale in SFSC (VALT), the percentage of sale in CFC (VCONV), and the percentage of revenues that derives from multifunctional activity (MULT). Finally, the demographic variables refer to percentage of workers employed that are less than 40 years old (AGE) and the percentage of workers that have a diploma and a degree (EDUC).

\section{Results}

Results show in the sample farms are efficiently working. Table 3 shows the results of the efficiency analysis considering the whole sample.

Technical efficiency (TE) analysis suggests that there is room for improving efficiency in the use of inputs. Especially the TE estimated through CRS reveals that farms have 
the possibility to further improve their efficiency on average by $30 \%$. The TE score is higher when it is calculated under VRS assumption, implying that the farms could improve their efficiency by $23 \%$. The scale efficiency (SE) is high, suggesting that adjusting the scale of the operation can improve the farm's efficiency on average by $10 \%$ (Table 3 ). The results on the standard deviation show a volatility of the sample in the TE scores.

Table 4 shows the results for both livestock and crops for the different performance measures. In the table, the overall efficiency $\left(\mathrm{TE}_{\mathrm{o}}\right)$ average scores compare livestock and crop farms considering them as part of the same production frontier, thus assuming that they have the same technological ground. The subgroup efficiency $\left(\mathrm{TE}_{\mathrm{g}}\right) \mathrm{com}$ pares livestock and crop farms considering them as part of two different frontier functions. The productivity index $(\phi)$ indicates the different technological ground of the two frontiers. Finally, the scale efficiency is calculated for the two farming systems in case the TE is estimated in the same frontiers (SE overall) or separately for crops and livestock farms (SE subgroup).

Results on the $\mathrm{TE}_{\mathrm{o}}$ show that livestock farms are more efficient than crops in the use of their inputs: livestock farms can improve their efficiency by $22 \%$, while crop farms by $24 \%$. In this case, scale efficiency (SE overall) is higher for livestock producers than crop farms (Table 4), suggesting that production could increase by about $8 \%$ if livestock farms could adjust their scale efficiency, a lower value compared to $11 \%$ of potential output increase for crop producers. None of these performance measures is significant implying that there is no significant difference between the two farming systems in reaching the optimal TE frontier. However, these measures are related to a unique frontier for both livestock and crop farms.

On the contrary, the productivity indexes $(\phi)$ for the two farming systems are statistically significant (Table 4). This result implies that the two farming systems lie on a different technological ground, and thus, they must be treated as having two different production frontiers. In the detail, livestock has a productivity index higher than crop farms, implying that livestock has a more productive technology than crop farms. Moreover, the results of the subgroup efficiency $\mathrm{TE}_{\mathrm{g}}$ scores show that when treated separately, crop farms are more efficient than livestock farms (0.87 versus 0.79$)$, and they also have a higher SE (0.95 versus 0.79$)$. These results suggest that crop farms are less productive than livestock farms because they use a less productive technology, since their productive index is lower. Nevertheless, considering the technology they have at disposition, crop farms are more efficient than livestock farms. On the contrary, livestock farms have a more productive technology, but considering their technology, they have lower TE scores.

Despite these differences, the fact that no significant difference is found between livestock and crops in the overall efficiency scores suggests that livestock farms could significantly improve the use of their inputs, and crop farms are able to compensate a less

Table 3 Efficiency analysis results from DEA

\begin{tabular}{lllll}
\hline & Average & s.d. & Max & Min \\
\hline $\mathrm{TE}^{\mathrm{CRS}}$ & 0.69 & 0.20 & 1.00 & 0.27 \\
$\mathrm{TE}$ & 0.77 & 0.23 & 1.00 & 0.29 \\
$\mathrm{SE}$ & 0.91 & 0.10 & 1.00 & 0.59 \\
\hline
\end{tabular}


Table 4 Estimation of TE by data envelopment analysis (DEA)

\begin{tabular}{|c|c|c|c|}
\hline & \multicolumn{2}{|c|}{ TE for the farming systems } & \multirow{2}{*}{$\begin{array}{l}p \\
\text { value }\end{array}$} \\
\hline & Crops (n. 25) & Livestock (n. 19) & \\
\hline \multicolumn{4}{|c|}{ Variable return to scale technical efficiency TE ${ }^{\mathrm{VRS}}$} \\
\hline Overall efficiency $\mathrm{TE}_{o}$ & 0.76 & 0.78 & n.s \\
\hline Subgroup efficiency $\mathrm{TE}_{g}$ & 0.87 & 0.79 & n.s \\
\hline Productivity index $\varphi$ & 0.84 & 0.99 & $* * *$ \\
\hline \multicolumn{4}{|l|}{ Scale efficiency } \\
\hline SE overall & 0.89 & 0.92 & n.s. \\
\hline SE subgroup & 0.95 & 0.79 & n.s \\
\hline
\end{tabular}

Note: $n$.s. denotes not statistically significance; *** denotes significance at $1 \%$.

productive technology with a more efficient use of the input. In other words, considering the frontier, crop farms are so efficient that they compensate their less productive technology.

Table 5 shows the role of single inputs-land, work, and variable costs-in describing the frontier, considering a unique frontier for the two farming systems, and considering two separate frontiers for the farming systems, and thus considering the subgroup efficiency. These results suggest which factors most affect the TE. Moreover, taking into account the observed and the optimal values, Table 5 shows the savings that could be possible in terms of input use, if inputs were used efficiently.

Table 5 Optimal (fully efficient) input use estimated by DEA (average values of TE VRS)

\begin{tabular}{|c|c|c|c|c|}
\hline & Observed values & Optimal values & $\mathrm{TE}$ & $\overline{\text { Savings }}$ \\
\hline \multicolumn{5}{|c|}{ Considering one frontier } \\
\hline \multicolumn{5}{|c|}{ Overall efficiency $\left(T E_{0}\right)$} \\
\hline Land (ha) & 78.59 & 64.80 & 0.80 & -13.79 \\
\hline Expe $\left(\epsilon^{\prime} 000\right)$ & 211.36 & 183.20 & 0.79 & -28.16 \\
\hline Work (€'000) & 121.74 & 92.51 & 0.79 & -29.22 \\
\hline \multicolumn{5}{|l|}{ Livestock } \\
\hline Land (ha) & 90.44 & 73.86 & 0.80 & -16.59 \\
\hline Expe $\left(€^{\prime} 000\right)$ & 346.50 & 308.42 & 0.81 & -38.08 \\
\hline Work (€'000) & 137.62 & 113.03 & 0.81 & -24.58 \\
\hline \multicolumn{5}{|l|}{ Crops } \\
\hline Land (ha) & 69.57 & 57.92 & 0.80 & -11.66 \\
\hline Expe $\left(€^{\prime} 000\right)$ & 108.65 & 88.04 & 0.78 & -20.62 \\
\hline Work (€'000) & 109.67 & 76.92 & 0.78 & -32.75 \\
\hline \multicolumn{5}{|c|}{ Considering two frontiers } \\
\hline \multicolumn{5}{|c|}{ Livestock subgroup efficiency $\mathrm{TE}_{g}$} \\
\hline Land (ha) & 90.44 & 71.95 & 0.79 & -18.49 \\
\hline Expe $\left(€^{\prime} 000\right)$ & 346.50 & 312.58 & 0.83 & -33.93 \\
\hline Work (€'000) & 137.62 & 115.57 & 0.83 & -22.05 \\
\hline \multicolumn{5}{|c|}{ Crop subgroup efficiency $\mathrm{TE}_{g}$} \\
\hline Land (ha) & 69.57 & 63.61 & 0.88 & -5.97 \\
\hline Expe $\left(\epsilon^{\prime} 000\right)$ & 108.65 & 95.43 & 0.86 & -13.23 \\
\hline Work (€'000) & 109.67 & 99.93 & 0.89 & -9.74 \\
\hline
\end{tabular}


In Table 5, higher values of TE indicate higher efficiency of the farms in the use of the inputs. The differences between the three estimates are not significant for both livestock and crops farms, both considering livestock and crops part of the same production frontier and not. This result implies that farmers seem to have a balance use of the inputs. In other words, farms are not organizing the production process with over- or under-exploiting any inputs. For this reason, farmers are acting rationally. Despite the fact that no input reaches the top of $\mathrm{TE}(\mathrm{TE}=1)$, this is an important result considering the constraints imposed by the park and by the regulation in using the inputs, especially land.

Imposing non-increasing return to scale (NIRS), it is possible to assess the farms' percentage under increasing (IRS), decreasing (DRS), and constant (CRS) return to scale (Table 6). In case of decreasing return to scale (DRS), farms are oversized with respect to their production, meaning that they are using too much input for the value of the output they are obtaining. On the contrary, in case of increasing return to scale (IRS), farms could increase the use of their inputs to increase more proportionally the output. In both livestock and crop farms, as well as in the overall sample, most of the farms are operating under IRS (Table 6). This result is coherent with the single-input TE estimates. Since no input is under- or overused, a balanced increase of all the inputs may lead the farms to improve the TE.

Finally, Table 7 shows the t-test operated on demographic variables (AGE and EDUC) and on economic variables (VALT, CONV and MULT). Despite farms seems more efficient when they participate in SFSCs and when they have multifunctional agriculture, there is no significant differences, both for livestock and for crops. In other words, in the case study, the diversification through SFSC and multifunctional agriculture does not significantly improve the TE of the farms. At the same time, no significance differences are found between farms with high percentage of young workers and for educated farmers for both livestock and crops farms.

\section{Discussion}

The overall purpose of this study was to analyze the technical efficiency (TE) of periurban farms. The analysis of TE is essential in sustainability studies, since TE emphasizes the farmer's decision-making, which in the end is the most important actor in fostering its economic sustainability (De Koeijer et al., 2002; Gonçalves et al., 2009). In this framework, considering that in the literature the diversification of the profit between

Table 6 Estimated return to scale by DEA

\begin{tabular}{llll}
\hline & CRS & IRS & DRS \\
\hline Sample (n. 44) & & & \\
$N$. & 10 & 26 & $18 \%$ \\
$\%$ & $22 \%$ & $59 \%$ & \\
Livestock (n. 19) & & & 2 \\
$N$. & 5 & 12 & $10 \%$ \\
$\%$ & $26 \%$ & $63 \%$ & \\
Crops (n. 25) & & & 4 \\
$N$. & 5 & 16 & $16 \%$ \\
$\%$ & $20 \%$ & $64 \%$ & \\
\hline
\end{tabular}


Table 7 t-test statistics for livestock and crops for different strategies of commercialization and for demographic variables; for the description of the code and the variables see Table 3

\begin{tabular}{llll}
\hline & VALT yes & VALT no & $\boldsymbol{p}$ value \\
\hline Livestock & 0.77 & 0.79 & n.s \\
Crops & 0.89 & 0.86 & n.s \\
MULT yes & MULT no & \\
Livestock & 0.78 & 0.78 & n.s. \\
Crops & 0.84 & 0.90 & n.s \\
& CONV yes & CONV no & \\
Livestock & 0.76 & 0.80 & n.s. \\
Crops & 0.90 & 0.85 & n.s \\
& AGE yes & AGE no & \\
Livestock & 0.74 & 0.85 & n.s. \\
Crops & 0.86 & 0.88 & n.s \\
Livestock & EDUC yes & EDUC no & \\
Crops & 0.72 & 0.83 & n.s. \\
\hline
\end{tabular}

different food chains and sectors is considered as a way to sustain the farming economy in periurban areas, this study has also assessed whether the farms' participation in SFSC and multifunctional agriculture affects the level of their TE. To be able to compare different farming systems localized in the same area and under the same political umbrella of an agri-park the study employed a data envelopment analysis (DEA) (Lansink et al., 2002). By the use of this model, it is possible to properly capture the heterogeneity in terms of the different farming systems-crops and livestock-and the different types of economic diversification, in order to provide specific insights for the policies carried out in the area. The novelty of this study relies on the fact that this is the first time that the DEA is applied in contexts of European PFS and using data from case study analysis and direct farm interviews. In this situation, the collecting of data led to have small sample. Nevertheless, analysis based on semi-structure interviews has the benefit to specifically picture the actual territorial situation of the farming system, which in the end is useful for both researchers and policy makers.

As in this study, literature has already compared the TE of livestock and crop farms in European countries (Latruffe et al., 2004; Hadley, 2006). Our studies go further, since beyond the identification of TE, it also identifies differences in the productivity between livestock and crops, as proposed by Lansink et al. (2002). By doing that, this study provides an important methodological insight. Since the model applied in this study does not assume any technological ground of the farming systems localized in one area, it resolves the issue of comparing TE of different farming systems localized in the same area. In this way, it contributes to the possibility to develop a territorial perspective in $\mathrm{TE}$ analysis. In fact, when the comparison between farming system is carried out, the only observation of the farms' TE scores does not resolve the question: are the differences in the performances related to the TE in itself, to a less productive technology, or both? (Mayen et al., 2010; Madau et al., 2018). Since our sample was composed of two farming systems localized in the same area, it is not enough to talk about TE, but we must also consider the different technological grounds they have. The statistical 
significant difference between the crop and livestock farms' productivity indexes resulting from our analysis suggests that any difference between the level of TE between them relies on the technology farmers have at disposition and not on the farmers' decision-making. At the same time, the analysis of the input-related TE shows that farmers are rationally using their inputs. In other words, according to our results, in the case study, farmers are well managing their farms. This is an important result considering our case study: it means that even if the permanence in an agricultural park may imply that farms need to adhere to rules and regulations (Perrin et al., 2018), this does not affect the way farmers allocate their resources among the inputs.

Considering the productivity of the two farming systems, the results suggest that in the PASM crop farms should invest in technologies more productive, which will result in a shift of the production frontier. In fact, the introduction of a technological innovation in a production system determines an improvement of its production capacities. On the contrary, the technologies applied on livestock farms have more potential than the technologies of crops to produce food using lower amount of inputs. This can be probably due to the fact that in the area livestock farms are highly specialized, while most of the crop farms combine permanent rice and other crops. The high specialization of livestock may also justify their less sub-group efficiency compared to crops. This is coherent with other studies, where less-specialized farms are generally more efficient than the morespecialized ones, perhaps because the more-specialized farms are less able to adapt to changing market and policy environments (Hadley, 2006).

In our study, even if the inputs are rationally used, findings suggest also that no inputs are used at their maximum capacity. In other words, there are spaces for improvements for all the three inputs: labor, land, variable costs. In the case of labor or variable costs, it is possible to conceive ways to further exploit their use, for example, by increasing the professional competences of workers. In fact, our results show that surprisingly the level of education does not significantly improve the level of efficiency, while usually in literature a high level of education is usually associated with higher scores of TE (Latruffe et al., 2004). In order to improve the effect of the labor in improving the $\mathrm{TE}$, we suggest that specific actions on education for professional farmers and employers could improve the level of efficiency, especially for livestock producers.

On the contrary, giving the case study an increasing use of land is almost impossible. The land in the metropolis' periurban fringe is a very scarce good: even when the agriculture is highly productive and efficient, as our results seem to suggest, the competition between different urban and agricultural purposes and between farmers makes it difficult for farmers to grow their surfaces. Moreover, the PASM area is considered as a vulnerable area for the EU Nitrates Directive, and the use of land is already strictly monitored and regulated, with limitations for farmers to use the land (Gaviglio and Pirazzoli, 2013).

Finally, this study is a preliminary analysis of the link between the economic diversification and TE in the frameworks of agro-urban projects. To our knowledge, no study has been carried out in PFS context, despite the fact that many scholars and institutional bodies have proposed SFSC and multifunctional agriculture as a way to maintain a sustainable farming system in metropolitan areas (Aubry and Kebir, 2013; Paül and Mackenzie, 2013). In our study, results suggest that the decision to sell in local markets does not induce distortions in the TE of periurban farmers, both for livestock and 
crops. In other words, the decision to sell in local markets is not a critical factor worsening the performance of farmers, as coherently with the few studies done on the subject in rural areas (Lohr and Park, 2010; Bauman et al., 2019). At the same time, according to our results, the participation in SFSC and multifunctional agriculture is not a factor in improving the efficiency for both livestock and crop farms. Thus, a question remains on how to make these activity drivers improve the technical efficiency and thus the economic sustainability. This result is relevant for the case study, since several actions in the PASM have been planned by public bodies to offer possibility to diversify the economy and improve the profitability of farms as a possible counterpart to urban sprawl (Heimlich et al., 2001). This result is coherent with previous studies which observed that in the area multifunctional activities were carried out more as a way to socially accept the presence of agriculture around the metropolis (Paül and Mackanzie, 2013) than to enhance the real economic sustainability of farms (Gaviglio et al., 2014). Policy actions should thus provide actions to better enhance the technical efficiency of farms that diversify their economy in different sectors and different food chains. In this way, those activities can effectively be a tool for the economic development of periurban farms and not just as a temporary activity where farmers may risk losing the efficient use of the inputs. The differentiated analysis on farming systems allows policy makers to identify what the effective needs of farms are to improve economic development. The more farms remain, the more peri-urban system is active and dynamic, capable of adapting to local changes.

\section{Conclusion}

To conclude, this analysis provides new insights on the TE and the productivity of farms at territorial scale. To our knowledge, this is the first time that the methodology has been applied in comparing farming systems at territorial scale. Results suggest that farmers of both crops and livestock farms rationally used their inputs, and they reach high levels of efficiency. Nevertheless, there is space to improve the TE, for example by improving the production technology in case of crops. The study also provides a preliminary analysis on the possible impact of SFSC and multifunctional agriculture on TE and resulting that at the moment they do not have an impact. Further analysis should deepen this issue, comparing the performances in terms of TE and productivity between different farming systems and production methods, and in different places, such as periurban and rural areas. In this way, it could be possible to further specify the conditions of the farm TE and to in the end foster their sustainability. The results of this analysis are valid for the case study, so we encourage other case study analysis to deepen the studies on TE at territorial scale. Considering the increasing policy actions addressed to PFS, a deeper knowledge of the agriculture performed around cities and the conditions for its economic sustainable maintenance is needed.

\section{Abbreviations}

PFS: Periurban farming system; PASM: South Agricultural Park of Milan; SFSC: Short food supply chains;

CFC: Conventional food chains; TE: Technical efficiency; DEA: Data envelopment analysis; UAA: Usable agricultural area;

DMU: Decision-making units (s); CRS: Constant return to scale; VRS: Variable return to scale; SE: Scale efficiency;

IRS: Increasing return to scale; DRS: Decreasing return to scale; NIRS: Non-increasing return to scale 
Authors' contributions

All authors in this paper variously contributed to the data collection, data analysis, and/or write-up of the manuscript. All authors read and approved the final manuscript.

\section{Funding}

Piano Sviluppo Ricerca 2018 Linea 2 Azione A e Azione B, Università degli Studi di Milano.

\section{Availability of data and materials}

The datasets generated and/or analyzed during the current study are not publicly available due to privacy, but are available from the corresponding author on reasonable request.

\section{Competing interests}

The authors declare that they have no competing interests.

\section{Author details}

${ }^{1}$ Department of Health, Animal Science and Food Safety, University of Milan, Via Celoria, 2, 20133 Milano, Italy.

${ }^{2}$ Department of Agricultural Sciences, University of Sassari, Viale Italia 39/A, 07100 Sassari, Italy.

Received: 11 October 2019 Revised: 24 March 2020

Accepted: 28 January 2021 Published online: 24 March 2021

\section{References}

Arru B, Furesi R, Madau FA, Pulina P (2019) Recreational services provision and farm diversification: a technical efficiency analysis on Italian agritourism. Agriculture 9(2):1-15

Asogwa BC, Umeh JC, Pend ST (2012) Technical efficiency analysis of small-holder farmers in rural and peri-urban areas of Nigeria. J Hum Ecol 37(1):57-66

Aubry C, Kebir L (2013) Shortening food supply chains: a means for maintaining agriculture close to urban areas? The case of the French metropolitan area of Paris. Food Policy 41:85-93

Bauer PW (1990) Recent developments in the econometric estimation of frontier. J Econ 46:39-56

Bauman A, Thilmany D, Jablonski BBR (2019) Evaluating scale and technical efficiency among farms and ranches with a local market orientation. Renew Agr Food Syst 34:198-206

Binam JN, Tonyè J, Wandji N, Nyambi G, Akoaa M (2004) Factors affecting the technical efficiency among smallholder farmers in the slash and burn agriculture zone of Cameroon. Food Policy 29(5):531-545

Charnes A, Cooper WW, Rhodes E (1978) Measuring the efficiency of decision-making units. Eur J Oper Res 2(6):429-444

Città Metropolitana di Milano (2007) Piano Territoriale di Coordinamento del Parco Agricolo Sud di Milano Piano del Settore Agricolo. Available via https://www.cittametropolitanamiit/export/sites/default/parco agricolo sud milano/content/allega ti/territorio pianificazione/PSA/norme/Norme regolamentaripdf. Accessed 15 Sept 2019

Coelli T (1996) A guide to DEAP version 21: a data envelopment analysis (computer) program. Available via http://www. owlnetriceedu/ econ380/DEAPPDF. Accessed 01 Apr 2019

Coelli T, Prasada D, George EB (1998) An introduction to efficiency and productivity analysis. Kluwar Academic Publications, USA

De Koeijer TJ, Wossink GAA, Struik PC, Renkema JA (2002) Measuring agricultural sustainability in terms of efficiency: the case of Dutch sugar beet growers. J Environ Manag 66:9-17

EEA - European Environment Agency (2006) Urban sprawl in Europe: the ignored challenge. Available via https://www.eea europaeu/publications/eea_report_2006_10. Accessed 01 Aug 2019

European Parliament (2018) Research for AGRI CommitteeUrban and peri-urban agriculture in the EU. Available at: https:// www.europarl.europa.eu/RegData/etudes/STUD/2018/617468/IPOL_STU(2018)617468_EN.pdf

FAO (2010) Food, agriculture and cities challenges of food and nutrition security, agriculture and ecosystem management in an urbanizing world. http://www.fao.org/fileadmin/templates/FCIT/PDF/FoodAgriCities_Oct2011.pdf. Accessed 20 June 2019

Filippini R, Lardon S, Bonari E, Marraccini E (2018) Unraveling the contribution of periurban farming systems to urban food security in developed countries. Agron Sustain Dev 38(2):21

Filippini R, Marraccini E, Houdart M, Bonari E, Lardon S (2016a) Food production for the city: hybridization of farmers' strategies between alternative and conventional food chains. Agroecol Sustain Food Syst 40(10):1058-1084

Filippini R, Marraccini E, Lardon S, Bonari E (2016b) Is the choice of a farm's commercial market an indicator of agricultural intensity? Conventional and short food supply chains in periurban farming systems. Ital J Agron 11(1):1-5. https://doi. org/10.4081/ija.2016.653

Furesi R, Madau FA, Pulina P (2013) Technical efficiency in the sheep dairy industry: an application on the Sardinian (Italy) sector. Agric Econ 1(4) https://doi.org/10.1186/2193-7532-1-4

Gaviglio A, Bertocchi M, Demartini E (2017) A tool for the sustainability assessment of farms: selection, adaptation and use of indicators for an Italian case study. Resources 6(4):60

Gaviglio A, Pirani A, Bertocchi M (2014) Development of the environmental, social and economic sustainability in the periurban agricultural areas: governance opportunities in the South Milan Agricultural Park. Adv Eng Forum 11:417-423

Gaviglio A, Pirazzoli C (2013) Stima dei costi di adeguamento alla Direttiva nitrati. In: Zootecnia e biogas. Incentivi 2013, Gaviglio A, Pirazzoli C, Ragazzoni A. Edizioni L'Informatorio Agrario S.r.l, Verona ISBN: 978-88-7220-319-4

Gomes EG, Soares de Mello JCCB, e Souza GS et al (2009) Efficiency and sustainability assessment for a group of farmers in the Brazilian Amazon. Ann Oper Res 169:167 https://doi.org/10.1007/s10479-008-0390-6

Greene W (2011) Stochastic frontier and efficiency estimation. Available via http://peoplesternnyuedu/wgreene/ FrontierModelshtm. Accessed 01 Oct 2019

Hadley D (2006) Patterns in technical efficiency and technical change at the farm-level in England and Wales, 1982-2002. J Agric Econ 57(1):81-100 
Heimlich, R, and Anderson, W (2001) Development at the urban fringe and beyond: impacts on agriculture and rural economic research service, US Department of Agriculture Whashington DC, USA. Available via http://www.ersusdagov/ publications/aer-agricultural-economic-report/aer803aspx. Accessed 20 Mai 2019

ISPRA - Istituto Superiore per la protezione e la Ricerca Ambientale (2015) II consumo di suolo in Italia. Available via http:// www.isprambientegovit/it/pubblicazioni/rapporti/il-consumo-di-suolo-in-italia-edizione-2015. Accessed 20 Mai 2019.

Jarosz L (2008) The city in the country: growing alternative food networks in metropolitan areas. J Rural St 24:231-244

Jarrige F, Chery JP, Buyck J, Gambier JP (2013) The Montpellier agglomeration: new approaches for territorial coordination in the periurban. In: Nilsson $\mathrm{K}$ et al (eds) Peri-urban futures; scenarios and models for land use change in Europe. Springer, New York/Dordrecht/Heidelberg/London, pp 241-274

Karimov AA (2014) Factors affecting efficiency of cotton producers in rural Khorezm, Uzbekistan: re-examining the role of knowledge indicators in technical efficiency improvement. Agric Econ 2(7) https://doi.org/10.1186/s40100-014-0007-0

Lansink AO, Pietola K, Bäckman S (2002) Efficiency and productivity of conventional and organic farms in Finland 1994-1997. Eur Rev Agric Econ 29(1):51-65

Latruffe L, Balcombe K, Davidova S, Zawalinska K (2004) Determinants of technical efficiency of crop and livestock farms in Poland. Appl Econ 36(12):1255-1263

Livanis G, Moss CB, Breneman VE, Nehring R (2006) Urban sprawl and farmland prices. Am J Agric Econ 88(4):915-929

Lohr L, Park T (2010) Local selling decisions and the technical efficiency of organic farms. Sustainability 2:189-203 https:// www.mdpi.com/2071-1050/2/1/189

Madau FA (2007) Technical efficiency in organic and conventional farming: evidence from Italian cereal farms. Agric Econ Rev 8(1):5-21

Madau FA (2015) Technical and scale efficiency in the Italian citrus farming: a comparison between SFA and DEA approaches. Agric Econ Rev 16(2):15-27

Madau FA, Furesi R, Pulina P (2018) The technical efficiency in Sardinian fisheries cooperatives. Mar Policy 95:111-116

Maietta OW (2007) L'analisi dell'efficienza Tecniche di base ed estensioni recenti. ESI, Napoli

Marraccini E, Lardon S, Loudiyi S, Giacché G, Bonari E (2013) Durabilité de l'agriculture dans les territoires périurbains méditerranéens: Enjeux et projets agriurbains dans la région de Pise (Toscane, Italie). Cah Agric 22:517-525

Mastronardi L, Marino D, Giaccio V et al (2019) Analyzing alternative food networks sustainability in Italy: a proposal for an assessment framework. Agric Econ 7(21) https://doi.org/10.1186/s40100-019-0142-8

Mayen CD, Balagtas JV, Alexander CE (2010) Technology adoption and technical efficiency: organic and conventional dairy farms in the United States. Am J Agric Econ 92(1):181-195

Opitz I, Berges R, Piorr A, Krikser T (2015) Contributing to food security in urban areas: differences between urban agriculture and peri-urban agriculture in the global north. Agric Hum Values 32:1-18

Paül V, McKenzie FH (2013) Peri-urban farmland conservation and development of alternative food networks: insights from a case-study area in metropolitan Barcelona (Catalonia, Spain). Land Use Policy 30:94-105

Perrin C, Nougarèdesa B, Sinia L, Branduini P, Salvatici L (2018) Governance changes in peri-urban farmland protection following decentralisation: a comparison between Montpellier (France) and Rome (Italy). Land Use Policy 70:536-546

Pirani A, Gaviglio A, Demartini E, Gelatini M, Cavicchioli D (2016) Studio delle determinanti del valore degli affitti agrari. Potenzialità dell'uso di microdati e applicazione del metodo dei prezzi edonici. Aestimum 69:131-151

Quon S (1999) Planning for urban agriculture: a review of tools and strategies for urban planners cities feed people rep 28 IDRC, Ottawa, Canada, p 81

Roco L, Bravo-Ureta B, Engler A, Jara-Rojas R (2017) The impact of climatic change adaptation on agricultural productivity in central Chile: a stochastic production frontier approach. Sustainability 9:1-16

Sali G, Provolo G, Riva E (2009) Rendita fondiaria e consumo di suolo agricolo. Riv Econ Agrar 3-4:465-484

Sokolow AD (2003) California's edge problem: urban impacts on agriculture. In: In California Agriculture Dimensions and Issues, ed. University of California Giannini Foundation of Agricultural Economics, Division of Agriculture and Natural Resources, Siebert

Soulard C-T, Valette E, Perrin C, Abrantes PC, Anthopoulou T, Benjaballah O, Bouchemal S, Dugué P, Amrani ME, Lardon S, Marraccini E, Mousselin G, Napoleone C, Paoli J-P (2017) Peri-urban agro-ecosystems in the Mediterranean: diversity, dynamics, and drivers. Reg Environ Chang https://doi.org/10.1007/s10113-017-1102-z

Theodoridis A, Ragkos A, Roustemis D, Arsenos G, Abas Z, Sinapis E (2014) Technical indicators of economic performance in dairy sheep farming. Animal 8(1):133-140

Torreggiani D, Dall'Ara E, Tassinari P (2012) The urban nature of agriculture: bidirectional trends between city and countryside. Cities 29:412-416

Van Rensburg TM, Mulugeta E (2016) Profit efficiency and habitat biodiversity: the case of upland livestock farmers in Ireland. Land Use Policy 54:200-211

Venn L, Kneafsey M, Holloway L, Cox R, Dowler E, Tuomainen H (2006) Researching European "alternative" food networks: some methodological considerations. Area 38:248-258

Zasada I (2011) Multifunctional peri-urban agriculture-a review of societal demands and the provision of goods and services by farming. Land Use Policy 28:639-648

Ženka L, Žufan P, Krtička L, Slach O (2016) Labour productivity of agricultural business companies and cooperatives in the Czech Republic: a micro-regional level analysis. Moravian Jeographical Rep 23(4):14-25

\section{Publisher's Note}

Springer Nature remains neutral with regard to jurisdictional claims in published maps and institutional affiliations. 